\title{
Cardiovascular benefits and risks of testosterone replacement therapy in hypogonadal men with type 2 diabetes mellitus and/or the metabolic syndrome: a systematic review
}

\author{
LE MINH QUANG, ${ }^{\text {ATUL KALHAN² }}$
}

\begin{abstract}
Background: Because of the paucity of large randomised controlled trials (RCTs) in men with type 2 diabetes mellitus (T2DM) and/or the metabolic syndrome (MS), the majority of evidence for use of testosterone replacement therapy (TRT) on the cardiovascular (CV) system in such men is derived from observational studies and systematic reviews. Methods: We carried out an extensive retrospective review of the literature, comparing the major comparative trials that involved TRT in hypogonadal men with T2DM and/or MS and focused on CV outcomes.

Results: Of 311 studies initially identified, 25 studies (12 RCTs and 13 non-RCTs) with a total number of 729,927 participants were deemed eligible for further review. Three RCTs and one non-RCT were excluded as these had not measured all-cause mortality and CV events as primary outcomes. Benefits of TRT on myocardial infarction were observed in two RCTs which were reviewed, while the rest demonstrated a neutral effect on CV events. In the non-RCTs, seven studies observed reduced all-cause mortality and/or major adverse CV events in the TRT group compared with the placebo group.

Conclusions: This retrospective and systematic review of the literature suggests protective effects of TRT against all-cause mortality and major adverse cardiac events in hypogonadal men with T2DM and/or MS, although these results need to be interpreted cautiously.
\end{abstract}

Br J Diabetes 2018;18:141-146

Chief Operating Officer cum Outpatient Clinic and Services Director, City International Hospital, Ho Chi Minh City and Consultant Diabetologist, Cardiff Diabetes Centre \& Centre for Research and Control of Diabetes, Ho Chi Minh City, Vietnam

Consultant Diabetes \& Endocrinology, Royal Glamorgan Hospital, Llantrisant and Honorary Consultant Endocrinologist, University Hospita of Wales, Cardiff, UK

Address for correspondence: Dr Le Minh Quang Cardiff Diabetes Centre/City International Hospital No 3, 17A Street, Binh Tri Dong B, Binh Tan District, Ho Chi Minh City, Vietnam E-mail: minhquang_I@cih.com.vn Imquang@gmail.com

https://doi.org/10.15277/bjd.2018.192
Key words: testosterone replacement, diabetes, cardiovascular events, men, hypogonadal

\section{Introduction}

Multiple studies have reported the development of hypogonadism in up to $40 \%$ of men with type 2 diabetes mellitus (T2DM), with up to $75 \%$ of such men presenting with symptoms of sexual dysfunction such as erectile dysfunction, loss of morning erection and low libido.1,2 There are observational studies which have shown an association between concentrations of testosterone $(T)$ and acute coronary events in men with or without T2DM. ${ }^{3,4}$ It is plausible that low $T$ levels contribute to endothelial dysfunction and impair coronary perfusion. ${ }^{5-7}$

There is emerging epidemiological data which suggest that low T levels are linked with an increased risk of cardiovascular disease (CVD).,8 Evidence from available observational studies has linked low $T$ concentrations with an increased all-cause mortality as well as $C V$ event rate. ${ }^{10-13}$ The severity of coronary artery disease ${ }^{14,15}$ and congestive heart failure ${ }^{16}$ correlates with the degree of $\mathrm{T}$ deficiency.

In contrast with these results, a few observational and metaanalysis studies have reported an increase in CV events such as myocardial infarction, stroke as well as death compared with controls in patients on testosterone replacement therapy (TRT). 17,18

Based on the contradictory evidence regarding the impact of TRT on CVD, the aim of our review is to examine the available evidence on the pros and cons of TRT on CVD in hypogonadal men with T2DM and/or metabolic syndrome (MS). As there is a paucity of well-designed, randomised, placebo-controlled trials of TRT, we have also included observational studies in our review. As only a small number of studies have been carried out exclusively in hypogonadal men with T2DM and/or MS, we have included all the trials in which the study population comprised a proportion of men with T2DM and/or MS.

\section{Methods}

In this systematic review we have followed the Preferred Reporting Items for Systematic Reviews and Meta-Analyses (PRISMA) checklist. ${ }^{19}$ 


\section{Data sources and searches}

We systematically searched PubMed, Cochrane Library, Google Scholar and Web of Science up to 30 June 2016 using search terms "testosterone" and/or "androgen", "testosterone replacement therapy" and/or "androgen replacement therapy", "diabetes mellitus" and "hypogonad*".

\section{Study selection}

We included all studies which had at least $15 \%$ of participants with T2DM. Studies in which TRT was used for $<4$ weeks were excluded as the short duration of pharmacotherapy was deemed to be insufficient to have any meaningful impact on CVD outcomes. Men who had used anabolic steroids for indications other than hypogonadism were excluded.

\section{Outcome}

The primary outcomes considered for this systematic review were the incidence of all-cause mortality and major adverse cardiac events (MACEs), which included fatal and non-fatal myocardial infarction (MI), stroke and heart failure.

\section{Quality assessment of studies and data extraction}

We developed a quality assessment table of the selected studies of the effects of TRT on CV events. ${ }^{20}$ Of the 25 selected studies, 12 studies were RCTs while 13 trials were non-RCTs. A total of three RCTs and nine non-RCTs had measured all-cause mortality and MACEs as primary outcomes.

To extract the data, the reviewer (LMQ) used the Cochrane data extraction form for reviews of interventions in RCTs and nonrandomised studies. Figure 1 shows the search strategy resulting in 25 placebo-controlled and untreated comparative trials.

\section{Results}

Initially we identified 311 articles related to TRT in men with hypogonadism. Only 40 of these 311 papers were deemed appropriate based on the eligibility criteria mentioned above. After reviewing the full text of these 40 papers, only 25 were found to be relevant comparative trials involving hypogonadal men who had received TRT for at least 4 weeks.

Table 1 shows the 25 selected trials which included 729,927 participants in 12 RCTs and 13 non-RCTs. Three RCTs and nine nonRCTs measured all-cause mortality and MACEs as primary outcomes. Three RCTs and one non-RCT were excluded as they had not measured all-cause mortality and CV events as primary outcomes. In treated groups, participants had received different testosterone formulations.

\section{Discussion}

Epidemiological and observational study-based data consistently support an increased prevalence of hypogonadism in men with T2DM and obesity (diabesity). ${ }^{46}$ The aetiopathogenesis of low T levels in men with diabesity is believed to be multifactorial, with reduced insulin and leptin signalling in the central nervous system playing a key role. ${ }^{46,47}$ A hypogonadotrophic hypogonadism state induced by an increased aromatase activity in visceral adipose tissue
Figure 1. Search strategy resulting in 25 placebo-controlled and untreated comparative trials

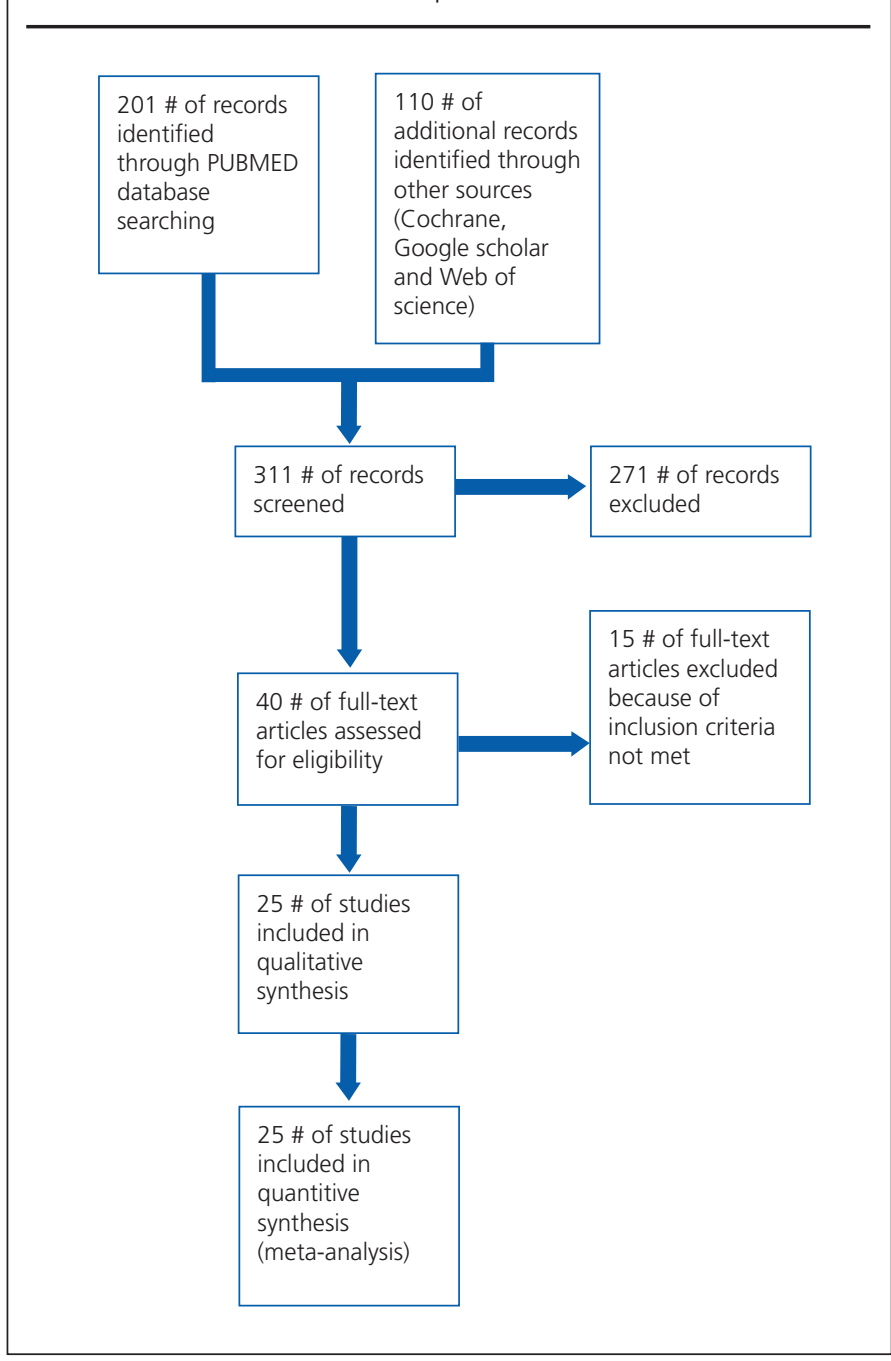

along with adipocyte-derived cytokines inhibiting gonadotrophin releasing hormone through an indirect effect on the kisspeptin pathway have also been implicated in the pathogenesis of hypogonadotrophic hypogonadism in men with diabetes and MS. ${ }^{48}$ We have carried out this systematic review to seek objective evidence regarding the impact of TRT on atherosclerotic CVD in hypogonadal men with T2DM and MS. We have analysed the available evidence from observational data and RCTs as well as reviewing the results of meta-analyses published during the last 15 years.

\section{Observational studies}

An observational study by Anderson et $a^{21}$ showed a significant reduction of MACEs in patients with normal T levels (attained with TRT) compared with the rates of MACEs in the low T group. In terms of safety differentiation by age, as expected, the event rates in the older group ( $>65$ years) were higher than the younger age group (<65 years). However, it is worth noting that, in both groups, the rates of 3-year mortality and MACEs were higher in persistently low T subjects. The strengths of this study include its large sample size 
Table 1 Characteristics of included studies

\begin{tabular}{|c|c|c|c|c|c|c|c|c|}
\hline Study authors & $\begin{array}{l}\text { Study } \\
\text { design }\end{array}$ & $\begin{array}{l}\text { Study } \\
\text { duration }\end{array}$ & Intervention & Comparators & $\begin{array}{l}\text { Numbers } \\
\text { of participants }\end{array}$ & $\begin{array}{l}\text { Age } \\
\text { (years) }\end{array}$ & $\begin{array}{l}\% \text { baseline } \\
\text { participants } \\
\text { with T2D }\end{array}$ & $\begin{array}{l}\text { Pharma- } \\
\text { ceutical } \\
\text { funding }\end{array}$ \\
\hline $\begin{array}{l}\text { Anderson et al } \\
(2015)^{21}\end{array}$ & Observational & 742 days & $\begin{array}{l}\text { Different formulations (gel: } 90 \% \text {, } \\
\text { injection: } 9.0 \% \text {, oral pill: } 1.0 \% \text { ) }\end{array}$ & Untreated & 4,736 & 61.2 & $\begin{array}{l}32.6 \% ; 29.3 \% \\
23.0 \%\end{array}$ & No \\
\hline $\begin{array}{l}\text { Aversa et al } \\
(2010)^{22}\end{array}$ & $\mathrm{RCT}$ & 24 months & IM TU 1000 mg every 12 weeks & PLB & T: 40 PLB: 10 & $58 / 57$ & $30 \%$ & No \\
\hline $\begin{array}{l}\text { Baillargeon et al } \\
(2014)^{23}\end{array}$ & $\begin{array}{l}\text { Retrospective } \\
\text { cohort }\end{array}$ & 1495 days & $\begin{array}{l}\text { IM different T formulations and dosing ( } \mathrm{T} \\
\text { enanthate or cypionate, up to } 1 \mathrm{~mL} \text {, up to } \\
100 \mathrm{mg} \text { and up to } 200 \mathrm{mg} \text {, T suspension, } \\
\text { up to } 50 \mathrm{mg} \text { ), T propionate, up to } 100 \mathrm{mg} \text { ) }\end{array}$ & Untreated & 6,355 & $>66$ & $\begin{array}{l}\text { Treated: } 19.7 \% \\
\text { Untreated: } 15.2 \%\end{array}$ & No \\
\hline $\begin{array}{l}\text { Dhindsa S et al } \\
(2016)^{24}\end{array}$ & $\mathrm{RCT}$ & 24 weeks & IM 250 mg TU every 2 weeks & PLB & T: 22 PLB: 22 & 54.6 & $100 \%$ & No \\
\hline $\begin{array}{l}\text { Francomano et al } \\
(2013)^{25}\end{array}$ & $\mathrm{RCT}$ & 60 months & IM TU 1000 mg every 6 weeks & PLB & T: 20 PLB: 20 & $58 / 57$ & $30 \%$ & No \\
\hline $\begin{array}{l}\text { Giagulli et al } \\
(2015)^{26}(26)\end{array}$ & Observational & 2 years & 100 mg T gel once daily & Untreated & 30 & 53.5 & $100 \%$ & No \\
\hline $\begin{array}{l}\text { Hackett et al } \\
(2014)^{27}\end{array}$ & $\mathrm{RCT}$ & 52 weeks & IM TU $1000 \mathrm{mg}$ at weeks 0,6 and 18 & PLB & T: 92 PLB: 98 & $61.2 / 62$ & $100 \%$ & No \\
\hline $\begin{array}{l}\text { Hackett et al } \\
(2016)^{28}\end{array}$ & $\mathrm{RCT}$ & 24 months & IM TU $1000 \mathrm{mg}$ at weeks 0,6 and 18 & PLB & T: 175 PLB: 682 & 63.5 & $100 \%$ & Yes \\
\hline $\begin{array}{l}\text { Haider et al } \\
(2014)^{29}\end{array}$ & Observational & 60 months & $\begin{array}{l}\text { IM TU } 1000 \text { mg at baseline and } 6 \text { weeks } \\
\text { and thereafter every } 12 \text { weeks }\end{array}$ & Untreated & 181 & 59.11 & $40 \%$ & No \\
\hline $\begin{array}{l}\text { Haider et al } \\
(2016)^{30}\end{array}$ & Observational & 7.3 years & IM TU 1000 mg at 3-monthly intervals & Untreated & 77 & 61 & $53 \%$ & No \\
\hline $\begin{array}{l}\text { Heufelder et al } \\
(2009)^{31}\end{array}$ & $\mathrm{RCT}$ & 52 weeks & T gel $50 \mathrm{mg}$ once daily & Untreated & $\begin{array}{l}\text { T: } 16 \\
\text { Untreated: } 16\end{array}$ & $57.3 / 55.9$ & $100 \%$ & No \\
\hline $\begin{array}{l}\text { Jones et al } \\
(2011)^{32}\end{array}$ & $\mathrm{RCT}$ & 12 months & Transdermal 60 mg T gel once daily & PLB & T: 108 PLB:112 & 59.9 & $62 \%$ & Yes \\
\hline $\begin{array}{l}\text { Kalinchenko et al } \\
(2010)^{33}\end{array}$ & $\mathrm{RCT}$ & 30 weeks & IM TU $1000 \mathrm{mg}$ at weeks 0,6 and 18 & PLB & T: 113 PLB: 71 & $51.6 / 52.8$ & $\begin{array}{l}\text { Treated: } 28.3 \% \\
\text { Placebo: } 33.8 \%\end{array}$ & Yes \\
\hline Li et al $(2016)^{34}$ & $\begin{array}{l}\text { Retrospective } \\
\text { cohort }\end{array}$ & 8 years & $\begin{array}{l}\text { Different T formulations and dosing } \\
\text { (topical/gel, transdermal, injections) }\end{array}$ & Untreated & 533,223 & $51.5 / 54.2$ & $20.2-20.8 \%$ & Yes \\
\hline $\begin{array}{l}\text { Malkin et al } \\
(2004)^{35}\end{array}$ & $\mathrm{RCT}$ & 12 weeks & IM 100 mg T every two weeks & PLB & T: 5 PLB: 5 & 60.8 & $50 \%$ & No \\
\hline $\begin{array}{l}\text { Martinez et al } \\
(2016)^{36}\end{array}$ & $\begin{array}{l}\text { Population based } \\
\text { case-control }\end{array}$ & 12 years & $\begin{array}{l}\text { Different } \mathrm{T} \text { formulations and dosing (IM, } \\
\text { transdermal and oral } \mathrm{T})\end{array}$ & Untreated & 19,215 & $64.8(15.2)$ & $14.7 \%$ & No \\
\hline $\begin{array}{l}\text { Mathur et al } \\
(2009)^{37}\end{array}$ & $\mathrm{RCT}$ & 12 months & $\begin{array}{l}\text { IM TU } 1000 \text { mg at weeks 2, 8, 20, } 32 \\
\text { and } 44\end{array}$ & PLB & T: 7 PLB: 6 & 65 & $23 \%$ & No \\
\hline $\begin{array}{l}\text { Muraleedharan } \\
\text { et al }(2013)^{38}\end{array}$ & $\begin{array}{l}\text { Prospective } \\
\text { follow-up }\end{array}$ & 41.6 months & $\begin{array}{l}\text { Different } \mathrm{T} \text { formulations and dosing (IM, } \\
\text { transdermal and oral T) }\end{array}$ & Untreated & 60 & 60.3 & $100 \%$ & Yes \\
\hline $\begin{array}{l}\text { Sharma et al } \\
(2015)^{39}\end{array}$ & Observational & 3 years & $\begin{array}{l}\text { Different T formulations and dosing } \\
\text { (injection, gel or patch) }\end{array}$ & Untreated & 83,010 & 66.5 & $\begin{array}{l}\text { Treated: } 30.3 \% \\
\text { Untreated: } 31.6 \%\end{array}$ & No \\
\hline $\begin{array}{l}\text { Sharma et al } \\
(2016)^{40}\end{array}$ & Observational & 15 years & $\begin{array}{l}\text { Different T formulations and dosing } \\
\text { (injection, gel or patch) }\end{array}$ & Untreated & 71,407 & $\begin{array}{l}64 ; 63.9 \\
66.6\end{array}$ & $\begin{array}{l}\text { Treated: } 30.4 \% \\
\text { Untreated: } 31.9 \%\end{array}$ & No \\
\hline $\begin{array}{l}\text { Shores et al } \\
(2012)^{3}\end{array}$ & Observational & 61 months & $\begin{array}{l}\text { Different T formulations and dosing } \\
\text { (injection, gel or patch) }\end{array}$ & Untreated & 1,031 & 62.1 & $\begin{array}{l}\text { Treated: } 35.9 \% \\
\text { Untreated: } 39.5 \%\end{array}$ & No \\
\hline $\begin{array}{l}\text { Stanworth et al } \\
(2014)^{41}\end{array}$ & $\mathrm{RCT}$ & 13 months & Transdermal 60 mg T gel once daily & PLB & T: 73 PLB: 66 & 59.9 & $100 \%$ & Yes \\
\hline Tan et al $(2013)^{42}$ & $\mathrm{RCT}$ & 48 weeks & IM TU 1000 mg every 10-14 weeks & PLB & T: 56 PLB: 58 & $53.8 / 51.3$ & $\begin{array}{l}\text { Treated: } 23.2 \% \\
\text { Placebo: } 15.5 \%\end{array}$ & Yes \\
\hline $\begin{array}{l}\text { Tong et al } \\
(2012)^{43}\end{array}$ & $\mathrm{RCT}$ & 48 weeks & $\begin{array}{l}\text { IM TU } 1000 \mathrm{mg} \text { at weeks } 0,6,18,30 \\
\text { and } 42\end{array}$ & PLB & T: 56 PLB: 58 & $53.4 / 53$ & $\begin{array}{l}\text { Treated: } 23.3 \% \\
\text { Placebo: } 15 \%\end{array}$ & Yes \\
\hline $\begin{array}{l}\text { Vigen et al } \\
(2013)^{44}\end{array}$ & $\begin{array}{l}\text { Retrospective } \\
\text { cohort study }\end{array}$ & 27.5 months & $\begin{array}{l}\text { Different } \mathrm{T} \text { formulations and dosing } \\
\text { (injection, gel or patch) }\end{array}$ & Untreated & 8,709 & $60 / 63$ & $\begin{array}{l}\text { Treated: } 53.2 \% \\
\text { Untreated: } 55.7 \%\end{array}$ & No \\
\hline
\end{tabular}

CV outcome, cardiovascular outcomes; IM, intramuscular; NR, not recorded; TRT, testosterone replacement therapy; IR, insulin resistance; PLB, placebo; RCT, randomised controlled trial; $\mathrm{T}$, testosterone; $\mathrm{TU}$, testosterone undecanoate 
with over 4,700 patients and meticulous follow-up of relevant medical records in a 'real-life' healthcare setting for more than 3 years.

In the retrospective study by Baillargeon et al, 23 TRT use was associated with a protective effect in hypogonadal men who were at highest risk of MI. It was suggested that $\mathrm{T}$ treatment might improve $\mathrm{CV}$ risks by reducing fat mass, improving insulin sensitivity and reducing cholesterol levels. The strength of this study was the analysis of a large cohort of patients with hypogonadism who received TRT $(n=6,335)$ and comparison with a well-matched cohort of T non-users $(n=19,065)$.

In a study by Muraleedharan et $a^{38}$ the mortality rate in association with TRT in men with T2DM was compared with a well-matched control group. A significantly increased rate of mortality was observed in the untreated group compared with the men with hypogonadism who received TRT. This study was the first longitudinal cohort study in hypogonadal men with T2DM that reported the value of baseline T level to predict a significantly increased risk of mortality rate during long-term follow-up. Importantly, the increased mortality was independent of other factors such as age, body mass index, smoking habit, glycaemic management, pre-existing CVD and medications. Although no significant increase in CV mortality was reported in the low $T$ group, there was an increased risk of CV death in men with below normal range $T$ levels compared with men with normal $T$ levels. Based on the study results, the authors concluded that the long-term use of TRT was associated with a reduced mortality rate in men with low $\mathrm{T}$ and T2DM.

Hackett et a/28 studied the impact of T therapy on clinical and metabolic measures for 24 months in 857 hypogonadal men with T2DM. Reduced mortality was observed in the men with normal $T$ and the low T group who were treated compared with the control group (men with low T who did not receive TRT).

In the observational study by Sharma et al, 39 normalised T levels were associated with a significantly increased Ml-free survival rate (log-rank, $\mathrm{p}<0.01)$, significantly lower stroke events and reduced all-cause mortality. The strength of this study is its large study cohort with an extensive follow-up duration. Shores et $a^{\beta}$ also observed that TRT use was associated with a reduction in mortality in hypogonadal men compared with the control group.

In contrast to the above-mentioned studies, an observational study carried out by Vigen et ${ }^{/ 44}$ reported an increased risk of mortality, MI or ischemic stroke with TRT use. This study was criticised for doubtful statis $\neg$ tical techniques, lack of adjustment for baseline $\mathrm{T}$ concentrations, inadequacy of $\mathrm{T}$ treatment in the study subjects and data corrections. For instance, $17.6 \%$ of participants in the treated group received only one prescription of TRT while a significant number of participants did not refill their prescription. Only $60 \%$ of patients had $\mathrm{T}$ levels tested post-treatment and the average post-treatment $\mathrm{T}$ levels were under the therapeutic target.

\section{Randomised controlled trials}

In the TIMES2 study, Jones et $a^{\beta 2}$ evaluated the efficacy and safety of T therapy on IR and CV risk factors and sexual symptoms in 220 hypogonadal men with T2DM and/or MS over 12 months. This double-blind, randomised, placebo-controlled, multi-centre study had one of the highest percentages of hypogonadal men with T2DM (62\%) included in the study group compared with the other available RCTs. CV events were observed to occur more commonly in the placebo group than in men who received TRT $(10.7 \%$ vs. $4.6 \% ; p=0.095)$. This study was criticised for overemphasising the improvement in glycaemic control and insulin sensitivity.

An RCT carried out by Aversa et a/22 and Tan et a/42 reported the beneficial role of TRT in hypogonadal men. There were an increased number of patients in the placebo group who experienced an acute coronary event compared to the patients on TRT.

\section{Meta-analysis}

In a meta-analysis, Xu et a/48 reported an increased risk of CV events with TRT use based on the trials which did not receive pharmaceutical industry funding. It was suggested that reporting of adverse outcomes with TRT may be open to a conflict of interest based on the source of funding. However, the authors did not classify CV events as the incidence of MACE. In a meta-analysis and systematic review of randomised trials, Corona et a/49 compared the effect of TRT against placebo and observed no increased risk of CV events.

In several meta-analyses and systematic reviews there has been no significant reported differences in terms of all-cause mortality and the incidence of $\mathrm{Ml}$, cardiac arrhythmias or revascularisation intervention between TRT and control groups. ${ }^{18,49-51}$ A recently published (May 2018) meta-analysis by Ponce et al analysed four RCTs which included a total of 1,779 patients on TRT therapy compared with placebo treatment. TRT was associated with improved sexual desire and erectile function although there was an increased risk of erythrocytosis. ${ }^{52}$

\section{Limitations}

The limitations of this review include a paucity in the number of large-scale RCTs in hypogonadal men with T2DM and/or MS, with most of the available literature being derived from observational studies. We included the studies in which T2DM patients constituted $>15 \%$ of total hypogonadal participants as there are only a limited number of studies carried out in men with T2DM. The impact of TRT in hypogonadal men with T2DM and/or MS is contentious with a lack of robust evidence based on RCTs, although epidemiological study-driven data suggest a beneficial effect of TRT as far as CVD mortality is concerned. Most trials only reported serious CV events as a primary outcome, although there was a lack of consistency in methodology to assess severity of CV events among the various trials. In addition, a lack of detailed CV event reporting secondary analysis (by subtype of CV event) was not always available. Such subgroup analysis would undoubtedly have added value in assessing the aetiopathogenesis of the event. The difference observed by source of funding could not just be chance variation, with most pharmaceutical-supported trials reporting positive outcomes.

RCTs in symptomatically hypogonadal participants with T2DM and/or MS need to be at least >1 year duration as shorter trials can potentially underestimate the impact of TRT on vascular endothelium. The mortality and MACEs should be pre-specified as the primary endpoints and should have a consistent definition. 


\section{Key messages}

- Type 2 diabetes mellitus and/or metabolic syndrome is associated with an increased prevalence of hypogonadotropic hypogonadism

- Low testosterone levels in men with type 2 diabetes mellitus and/or metabolic syndrome are associated with increased cardiovascular mortality

- Testosterone replacement therapy in men with type 2 diabetes mellitus and/or metabolic syndrome is associated with reduced all-cause mortality and major adverse cardiac events, although testosterone replacement therapy needs to be used cautiously in elderly men with multiple co-morbidities

\section{Conclusions}

Our retrospective and systematic review of the literature suggests an increased risk of all-cause mortality and CV events in men with low endogenous T levels. ${ }^{53-55}$ An extensive analysis of published data (available on 30 June 2016) from RCTs and non-RCTs is supportive of the protective effect of TRT on all-cause mortality and MACEs in hypogonadal men with T2DM and/or MS. However, caution needs to be exercised while considering TRT in elderly men with co-morbidities. There is also a need for larger double-blind RCTs to evaluate the long-term outcome of TRT in hypogonadal men.

Conflict of interest The authors declare no support from any organisation for the submitted work.

Authors' contributions LMQ carried out the systematic search and drafted the manuscript. LMQ and AK did the data extraction and analysis; they also reviewed the manuscript critically. AK helped to carry out the systematic search and draft the manuscript. Both authors had full access to all the data in the study and take responsibility for the integrity of the data and the accuracy of the data analysis. Both authors read and approved the final manuscript.

Acknowledgements The author would like to thank Atul Kalhan for his strong support in developing and writing this review.

\section{Funding None.}

\section{References}

1. Kapoor D, Aldred H, Clark S, Channer KS, Jones TH. Clinical and biochemical assessment of hypogonadism in men with type 2 diabetes: correlations with bioavailable testosterone and visceral adiposity. Diabetes Care 2007;30:911-17

2. Dhindsa S, Prabhakar S, Sethi M, Bandyopadhyay A, Chaudhuri A, Dandona P. Frequent occurrence of hypogonadotropic hypogonadism in type 2 diabetes. J Clin Endocrinol Metab 2004;89:5462-8.

3. Shores MM, Smith NL, Forsberg CW, et al. Testosterone treatment and mortality in men with low testosterone levels. J Clin Endocrinol Metab 2012;97:2050-8. https://doi.org/10.1210/jc.2011-2591

4. Muraleedharan $\mathrm{V}$, Marsh $\mathrm{H}$, Kapoor $\mathrm{D}$, et al. Testosterone treatment is associated with increased risk of mortality and testosterone replacement improves survival in men with type 2 diabetes. Eur J Endocrinol 2013; 169:725-33. https://doi.org/10.1530/EJE-13-0321

5. English KM, Steeds RP, Jones TH, Diver MJ, Channer KS. Low-dose transdermal testosterone therapy improves angina threshold in men with chronic stable angina: a randomized, double-blind, placebo-controlled study. Circulation 2000;102:1906-11.

6. Rosano GM, Leonardo F, Pagnotta P, et al. Acute anti-ischemic effect of testosterone in men with coronary artery disease. Circulation 1999; 99:1666-70

7. Webb CM, Adamson DL, de Zeigler D, Collins P. Effect of acute testosterone on myocardial ischemia in men with coronary artery disease. Am J Cardiol 1999;83:437-9.

8. Jones TH. Testosterone deficiency: a risk factor for cardiovascular disease? Trends Endocrinol Metab 2010;21:496-503. https://doi.org/10.1016/j.tem.2010.03.002

9. Traish AM, Saad F, Feeley RJ, Guay A. The dark side of testosterone deficiency: III. Cardiovascular disease. J Androl 2009;30:477-94. https://doi.org/10.2164/jandrol.108.007245

10. Khaw KT, Dowsett $\mathrm{M}$, Folkerd $\mathrm{E}$, et al. Endogenous testosterone and mortality due to all causes, cardiovascular disease, and cancer in men: European Prospective Investigation into Cancer in Norfolk (EPIC-Norfolk) prospective population study. Circulation 2007;116:2694-701. https://doi.org/10.1161/CIRCULATIONAHA.107.719005

11. Haring R, Völzke $H$, Steveling $A$, et al. Low serum testosterone levels are associated with increased risk of mortality in a population-based cohort of men aged 20-79. Eur Heart J 2010;31:1494-501. https://doi.org/10.1093/eurheartj/ehq009

12. Laughlin GA, Barrett-Connor E, Bergstrom J. Low serum testosterone and mortality in older men. J Clin Endocrinol Metab 2008;93:68-75. https://doi.org/10.1210/jc.2007-1792

13. Zhao SP, Li XP. The association of low plasma testosterone level with coronary artery disease in Chinese men. Int J Cardiol 1998;63:161-4.

14. Rosano G, Sheiban I, Massaro R, et al. Low testosterone levels are associated with coronary artery disease in male patients with angina. Int $J$ Impot Res 2007;19:176-82. https://doi.org/10.1038/sj.ijir.3901504

15. Li L, Guo CY, Jia EZ, et al. Testosterone is negatively associated with the severity of coronary atherosclerosis in men. Asian J Androl 2012;14:8758. https://doi.org/10.1038/aja.2012.95

16. Jankowska EA, Biel B, Majda J, et al. Anabolic deficiency in men with chronic heart failure: prevalence and detrimental impact on survival. Circulation 2006;114:1829-37. https://doi.org/10.1161/CIRCULATIONAHA.106.649426

17. Xu L, Freeman G, Cowling B, Schooling C. Testosterone and cardiovascular related events in men: a meta-analysis of randomized controlled trials. BMC Med 2013;11:108. https://doi.org/10.1186/1741-7015-11-108

18. Calof $O M$, Singh $A B$, Lee $M L$, et al. Adverse events associated with testosterone replacement in middle-aged and older men: a meta-analysis of randomised, placebo-controlled trials. J Gerontol A Biol Sci Med Sci 2005; 60:1451-7.

19. Moher D, Liberati A, Tetzlaff J, Altman DG. The PRISMA Group. Preferred Reporting Items for Systematic Reviews and Meta-Analyses: The PRISMA Statement. PLoS Med 2009;6(7):e1000097. https://doi.org/10.1371/journal.pmed1000097.

20. Higgins JPT, Green S, eds. Cochrane Handbook for Systematic Reviews of Interventions, Version 5.1.0 (updated March 2011). The Cochrane Collaboration, 2011. Available from http://handbook.cochrane.org

21. Anderson JL, May HT, Lappe DL, et al. Impact of testosterone replacement therapy on myocardial infarction, stroke, and death in men with low testosterone concentrations in an integrated health care system. Am J Cardiol 2016;117:794-9. https://doi.org/10.1016/j.amjcard.2015.11.063

22. Aversa A, Bruzziches R, Francomano D, et al. Effects of testosterone undecanoate on cardiovascular risk factors and atherosclerosis in middleaged men with late-onset hypogonadism and metabolic syndrome: results from a 24-month, randomized, double-blind, placebo-controlled study. J Sexual Med 2010;7:3495-503.

https://doi.org/10.1111/j.1743-6109.2010.01931.x

23. Baillargeon J, Urban RJ, Kuo YF, et al. Risk of myocardial infarction in older men receiving testosterone therapy. Ann Pharmacother 2014;48:1138-44. https://doi.org/10.1177/1060028014539918

24. Dhindsa S, Ghanim H, Batra M, et al. Insulin resistance and inflammation in hypogonadotropic hypogonadism and their reduction after testosterone replacement in men with type 2 diabetes. Diabetes Care 
2016;39:82-91. https://doi.org/10.2337/dc15-1518

25. Francomano D, Lenzi A, Aversa A. Effects of five-year treatment with testosterone undecanoate on metabolic and hormonal parameters in ageing men with metabolic syndrome. Int J Endocrinol 2014; 2014:527470. https://doi.org/10.1155/2014/527470.

26. Giagulli VA, Carbone MD, Ramunni MI, et al. Adding liraglutide to lifestyle changes, metformin and testosterone therapy boosts erectile function in diabetic obese men with overt hypogonadism. Andrology 2015;3:1094-103. https://doi.org/10.1111/andr.12099

27. Hackett $\mathrm{G}$, Cole N, Bhartia M, et al. The response to testosterone undecanoate in men with type 2 diabetes is dependent on achieving threshold serum levels (the BLAST study). Int J Clin Pract 2014;68:203-15. https://doi.org/10.1111/ijcp.12235

28. Hackett G, Heald AH, Sinclair A, Jones PW, Strange RC, Ramachandran $\mathrm{S}$. Serum testosterone, testosterone replacement therapy and all-cause mortality in men with type 2 diabetes: retrospective consideration of the impact of PDE5 inhibitors and statins. Int J Clin Pract 2016;70:24453. https://doi.org/10.1111/ijcp.12779

29. Haider A, Saad F, Doros G, Gooren L. Hypogonadal obese men with and without diabetes mellitus type 2 lose weight and show improvement in cardiovascular risk factors when treated with testosterone: an observational study. Obes Res Clin Pract 2014;8:e339-49. https://doi.org/10.1016/j.orcp.2013.10.005

30. Haider A, Yassin A, Haider KS, Doros G, Saad F, Rosano GM. Men with testosterone deficiency and a history of cardiovascular diseases benefit from long-term testosterone therapy: observational, real-life data from a registry study. Vasc Health Risk Manage 2016;12:251-61. https://doi.org/10.2147NHRM.S108947

31. Heufelder AE, Saad F, Bunck MC, Gooren L. Fifty-two-week treatment with diet and exercise plus transdermal testosterone reverses the metabolic syndrome and improves glycemic control in men with newly diagnosed type 2 diabetes and subnormal plasma testosterone. J Androl 2009;30:726-33. https://doi.org/10.2164/jandrol.108.007005

32. Jones TH, Arver S, Behre HM, et al. Testosterone replacement in hypogonadal men with type 2 diabetes and/or metabolic syndrome (the TIMES2 study). Diabetes Care 2011;34:828-37. https://doi.org/10.2337/dc10-1233

33. Kalinchenko SY, Tishova YA, Mskhalaya GJ, Gooren LJ, Giltay EJ, Saad F. Effects of testosterone supplementation on markers of the metabolic syndrome and inflammation in hypogonadal men with the metabolic syndrome: the double-blinded placebo-controlled Moscow study. Clin Endocrinol 2010;73:602-12.

https://doi.org/10.1111/j.1365-2265.2010.03845.x

34. Li H, Benoit K, Wang W, Motsko S. Association between use of exogenous testosterone therapy and risk of venous thrombotic events among exogenous testosterone treated and untreated men with hypogonadism. J Urol 2016;195(4 Pt 1):1065-72. https://doi.org/10.1016/j.juro.2015.10.134

35. Malkin CJ, Pugh PJ, Morris PD, et al. Testosterone replacement in hypogonadal men with angina improves ischaemic threshold and quality of life. Heart 2004;90:871-6. https://doi.org/10.1136/hrt.2003.021121

36. Martinez C, Suissa S, Rietbrock S, et al. Testosterone treatment and risk of venous thromboembolism: population based case-control study. BMJ 2016;355:i5968. https://doi.org/10.1136/bmj.i5968

37. Mathur A, Malkin C, Saeed B, Muthusamy R, Jones TH, Channer K. Long-term benefits of testosterone replacement therapy on angina threshold and atheroma in men. Eur J Endocrinol 2009;161:443-9. https://doi.org/10.1530/EJE-09-0092

38. Muraleedharan V, Marsh H, Kapoor D, Channer KS, Jones TH. Testosterone deficiency is associated with increased risk of mortality and testosterone replacement improves survival in men with type 2 diabetes. Eur J Endocrinol 2013;169:725-33. https://doi.org/10.1530/EJE-13-0321

39. Sharma R, Oni OA, Chen G, et al. Association between testosterone re- placement therapy and the incidence of DVT and pulmonary embolism: a retrospective cohort study of the Veterans Administration Database. Chest 2016;150:563-71. https://doi.org/10.1016/j.chest.2016.05.007

40. Sharma R, Oni OA, Gupta K, et al. Normalization of testosterone level is associated with reduced incidence of myocardial infarction and mortality in men. Eur Heart J 2015:36:2706-15. https://doi.org/10.1093/eurheartj/ehv346

41. Stanworth RD, Akhtar S, Channer KS, Jones TH. The role of androgen receptor CAG repeat polymorphism and other factors which affect the clinical response to testosterone replacement in metabolic syndrome and type 2 diabetes: TIMES2 sub-study. Eur J Endocrino/ 2014;170:193200. https://doi.org/10.1530/EJE-13-0703

42. Tan WS, Low WY, Ng CJ, et al. Efficacy and safety of long-acting intramuscular testosterone undecanoate in aging men: a randomised controlled study. BJU Int 2013;111:1130-40.

https://doi.org/10.1111/bju.12037

43. Tong SF, Ng CJ, Lee BC, et al. Effect of long-acting testosterone undecanoate treatment on quality of life in men with testosterone deficiency syndrome: a double blind randomized controlled trial. Asian J Androl 2012;14:604-11. https://doi.org/10.1038/aja.2011.178

44. Vigen $\mathrm{R}$, O'Donnell $\mathrm{Cl}$, Baron AE, et al. Association of testosterone therapy with mortality, myocardial infarction, and stroke in men with low testosterone levels. JAMA 2013;310:1829-36.

https://doi.org/10.1001/jama.2013.280386

45. Dhindsa S, Ghanim H, Batra M, Dandona P. Hypogonadotropic hypogonadism in men with diabesity. Diabetes Care 2018;41:1516-25. https://doi.org/10.2337/dc17-2510

46. Grossman M. Hypogonadism and male obesity: focus on unresolved questions. Clin Endocrinol 2018;89:11-21. https://doi.org/10.1111/cen.13723

47. Dudek M, Ziamiak K, Sliwowska JH. Kisspeptin and metabolism: the brain and beyond. Front Endcrinol (Lausanne) 2018;9:145. https://doi.org/10.3389/fendo.2018.00145

48. Xu L, Freeman G, Cowling BJ, Schooling CM. Testosterone therapy and cardiovascular events among men: a systematic review and meta-analysis of placebo-controlled randomized trials. BMC Med 2013;11:108. https://doi.org/10.1186/1741-7015-11-108

49. Corona G, Maseroli E, Rastrelli G, et al. Cardiovascular risk associated with testosterone-boosting medications: a systematic review and metaanalysis. Expert Opin Drug Saf 2014;13:1327-51.

https://doi.org/10.1517/14740338.2014.950653

50. Haddad RM, Kennedy CC, Caples SM, et al. Testosterone and cardiovascular risk in men: a systematic review and meta-analysis of randomized placebo-controlled trials. Mayo Clin Proc 2007;82:29-39. https://doi.org/10.4065/82.1.29

51. Fernández-Balsells $\mathrm{MM}$, Murad $\mathrm{MH}$, Lane $\mathrm{M}$, et al. Clinical review 1 : adverse effects of testosterone therapy in adult men: a systematic review and meta-analysis. J Clin Endocrinol Metab 2010;95:2560-75. https://doi.org/10.1210/jc.2009-2575

52. Ponce OJ, Spencer-Bonilla G, Alvarez-Villalobos N, et al. The efficacy and adverse events of testosterone replacement therapy in hypogonadal men: a systemic review of randomised, placebo controlled trials. J Clin Endocrinol Metab 2018;103:1745-54. https://doi.org/10.1210/jc.2018-00404

53. Menke A, Guallar E, Rohrmann S, et al. Sex steroid hormone concentrations and risk of death in US men. Am J Epidemiol 2010;171:58392. https://doi.org/10.1093/aje/kwp415

54. Laughlin GA, Barrett-Connor E, Bergstrom J. Low serum testosterone and mortality in older men. J Clin Endocrinol Metab 2008;93:68-75. https://doi.org/10.1210/jc.2007-1792

55. Malkin CJ, Pugh PJ, Morris PD, Asif S, Jones TH, Channer KS. Low serum testosterone and increased mortality in men with coronary heart disease. Heart 2010;96:1821-5. https://doi.org/10.1136/hrt.2010.195412 